Tersedia online di:http://ejournal-balitbang.kkp.go.id/index.php/jkpi
e-mail:jkpi.puslitbangkan@gmail.com
JURNAL KEBIJAKANPERIKANANINDONESIA
Volume 11 Nomor 2 November 2019
p-ISSN: 1979-6366
e-ISSN: 2502-6550
Nomor Akreditasi Kementerian RISTEKDIKTI: 21/E/KPT/2018

\title{
RESOLUSI KONFLIK NELAYAN DI PERAIRAN TERITORIAL
} KABUPATEN KOTABARU

\section{FISHERY CONFLICT RESOLUTION IN KOTABARU WATER TERRITORIAL}

\author{
Rusmilyansari $^{\star 1}$ dan Emmy Sri Mahreda ${ }^{1}$ \\ ${ }^{1}$ Fakultas Perikanan dan Kelautan Unlam, JI. A. Yani Km 36 PO Box 6 Banjarbaru, Kalimantan Selatan, Indonesia \\ Teregistrasi I tanggal: 06 Oktober 2017; Diterima setelah perbaikan tanggal: 27 Desember 2019; \\ Disetujui terbit tanggal: 13 Januari 2020
}

\begin{abstract}
ABSTRAK
Penelitian ini bertujuan: Mengetahui Tipologi konflik, Mengembangkan resolusi konflik dan memetakan kelembagaan resolusi konflik. Penelitian menggunakan metode studi kasus. Data bersumber pada data primer dan sekunder. Pengumpulan data primer dilakukan dengan cara observasi dan metode snowballing melalui key informan. Data sekunder dikumpulkan berdasarkan dokumen-dokumen di masa lalu serta klipping surat kabar. Data dianalisis secara deskriptif, spot mapping, times line. Hasil Penelitian menunjukkan bahwa: (1) Konflik nelayan pada kasus pembagian daerah penangkapan ikan merupakan tipologi yuridiksi perikanan, nelayan masih menganut pola pembagian zona daerah penangkapan tradisional. Konflik nelayan pada kasus perbedaan alat tangkap tradisional dan modifikasi termasuk tipologi alokasi internal dan mekanisme pengelolaan. Masalah lainnya adalah adanya perbedaan posisi, kebutuhan, kepentingan, pandangan dan konteks dikalangan nelayan dalam posisi yang sama. (2) Resolusi konflik lampara dasar diselesaikan dengan cara negosiasi secara kekeluargaan, tidak ada kesepakatan tertulis. Resolusi konflik dapat juga terjadi secara avoidance yang berhenti dengan sendirinya berdasarkan kesadaran masingmasing. (3) Lembaga yang terlibat dalam penyelesaian konflik yaitu DKP Kalsel, DKP Kotabaru, INSAN, TNI AL, Polair, Polres/Polsek, WALHI, DPRD, POKMASWAS. Diperlukan teknologi komunikasi informasi yang dapat diterima dengan cepat agar konflik dapat terdeteksi sedini mungkin
\end{abstract}

Kata Kunci: Resolusi; Konflik; nelayan; perairan; teritorial; Kotabaru

\begin{abstract}
The objectives of this study are: finding out the typology of conflict, develop conflict resolution and mapping the institutional conflict resolution. The study used case study method. Data is sourced from primary and secondary data. Primary data collection is done by observation and snowballing method through key informant. Secondary data are collected based on past documents and newspaper clippings. Data were analyzed descriptively, spot mapping and times line. The results of the research show (1) Fisherman conflicts in the case of division of fishing areas is a typology of fishery jurisdiction in which fishermen still adhere to the traditional zone pattern of fishing areas. Conflicts in traditional fishing gear warfare cases and modifications was part of the internal allocation typology and management mechanisms. Other sources of conflict were different positions, needs, interests, views and context among fishermen in the same position. (2) Conflict resolution due to the use of lampara dasar (mini trawl) is settled by means of a familial negotiation, no written agreement. Avoidance is another Conflict resolution, based on their respective awareness. (3) Institutions involved in conflict resolution are DKP Kalsel, DKP Kotabaru, INSAN, TNI AL, Polair, Polres / Polsek, WALHI, DPRD, POKMASWAS. There is a need for information communications technology that can be received quickly so that the conflict can be detected as early as possible.
\end{abstract}

Keywords: Resolution; Conflict; fishermen; waters; territorial; Kotabaru 


\section{PENDAHULUAN}

Kelimpahan sumberdaya di wilayah pesisir yang meliputi perikanan, mangrove, terumbu karang, kandungan minieral, minyak, gas, serta jasa lingkungan untuk transportasi dan pariwisata menjadi daya tarik ekonomi untuk mengekploitasinya (Rusmilyansari et al., 2013). Eksploitasi perikanan di Perairan Teritorial Kabupaten Kotabaru antara lain dilakukan di Selat Makasar, Selat Laut dan Selat Sebuku, Teluk Pamanukan, Tanjung Tatan, Pulau Sambar Gelap, Sekapung, dan pesisir lainnya. Konflik nelayan di Kabupaten Kotabaru merupakan suatu kenyataan yang sepertinya tidak terpisahkan dari kehidupan masyarakat. Cukup banyak fakta kekerasan fisik akibat dari konflik yang telah terjadi. Kejadian-kejadian dimasa lalu yang mempunyai kaitan atau berkontribusi terhadap terjadinya konflik nelayan (Rusmilyansari, 2012).

Priscoli (2002) menyatakan bahwa konflik sumber daya alam dapat disebabkan antara lain perbedaan kepentingan dan faktor struktural. Konflik perikanan tangkap sangat bervariasi antar wilayah dan antar waktu. Bennett \& Neiland (2000) menyatakan bahwa konflik bersifat multidimensional dan umumnya melibatkan berbagai pihak dalam hubungan yang kompleks.

Konflik perikanan tangkap secara umum terkait dengan pemanfaatan sumber daya ikan yang sudah tergolong langka. Kelangkaan dimaksud terkait dengan masalah produksi, yaitu semakin sedikitnya ikan yang dapat ditangkap oleh nelayan. Pada umumnya, pihak-pihak yang terlibat dalam konflik adalah kelompok nelayan tradisional.

Penelitian ini merupakan upaya untuk memahami akar permasalahan konflik yang terjadi di perairan Teritorial Kotabaru Kalimantan Selatan, dengan menggunakan tahapan-tahapan yang perlu dilakukan yang ditetapkan secara ilmiah. Secara spesifik penelitian ini bertujuan untuk mengetahui Tipologi dan eskalasi Konflik, Memetakan resolusi konflik, serta memetakan kelembagaan pengelolaan konflik daerah penangkapan di perairan Teritorial Kotabaru.

\section{KERANGKA PEMIKIRAN}

Konflik perikanan tangkap bersifat sangat kompleks. Penelitian dilakukan berdasarkan kasus yang terjadi di Kabupaten Kotabaru Kalimantan Selatan. Data bersumber pada data primer dan sekunder untuk memperoleh identifikasi menyeluruh yang merupakan input dari penelitian yang terangkum kedalam identifikasi permasalahan konflik perikanan tangkap. Akar permasalahan penting untuk diketahui agar penyelesaian terhadap kesepakatan diharapkan benar-benar dapat meyelesaikan masalah. Identifikasi awal yang dilakukan secara sistematis merupakan landasan yang kuat dalam menjalankan proses penyelesaian konflik.Data tersebut terkumpul dengan cara observasi dan metode snowballing melalui key informan.

Data sekunder dikumpulkan berdasarkan dokumen-dokumen di masa lalu serta klipping surat kabar. Data dianalisis secara deskriptif kemudian didapatkan times line berdasarkan sejarang terjadinya konflik dalam rentang waktu yang lama. Sumber konflik ini seringkali timbul karena adanya perbedaan pemanfaatan sumber daya atau perbedaan dalam cara pengelolaannya. Perbedaan pendapat juga terjadi ketika masing-masing memiliki kepentingan yang saling tidak mendukung, atau ketika prioritas dari beberapa kelompok pengguna tidak terwakili dalam kebijakan dan program yang ada. Perbedaan tersebut tergambarkan dalam segitiga S-P-K (Sikap Perilaku Konteks). Untuk lebih memahami konflik secara lebih jelas perlu dilakukan pemetaan konflik yang menggambarkan konflik secara grafis, menghubungkan pihak-pihak beserta masalahnya dan pihak lainnya yang terlibat dalam konflik yang bersangkutan.

Resolusi konflik dapat ditempuh dengan menggunakan dua pendekatan yaitu melalui pengadilan (litigasi) atau pendekatan alternatif yang lebih dikenal sebagai alternative dispute resolution (ADR). Untuk dapat melakukan proses resolusi konflik yang efektif tentu saja memerlukan wadah kelembagaan, melalui suatu forum dapat ditentukan teknik resolusi yang tepat, sehingga mekanisme penyelesaian konflik dapat mencapai kesepakatan yang disetujui oleh segenap stakeholderyang terkaitsesuai dengan akar masalahnya. Dengan demikian implikasinya dapat diterapkan dalam pengelolaan konflik.

\section{HASIL PENELITIAN Penahapan Konflik}

Penahapan konflik digambarkan kedalam grafik eskalasi konflik yang disajikan pada Gambar 1. Kondisi prakonflik terjadi pada tahun 1960-1979. Pada masa ini sumber daya yang tersedia masih banyak sehingga kehadiran nelayan dari manapun tidak dirasakan nelayan lokal sebagai pesaing dalam memanfaatkan sumberdaya. Sifat sumber daya perikanan laut yang bersifat open access memungkinkan semua pihak untuk melakukan ekspoitasi tanpa terikat kuat pada batas-batas wilayah. 
Periode tahun 1980-1999, 2001-2004 dan 2006 (konfrontasi). Pada periode ini beberapa nelayan di Kotabaru ada yang masih menerapkan adanya pola penguasaan dan kepemilikan wilayah laut oleh kelompok masyarakat. Pola tersebut terbagi berdasarkan zona daerah tangkap nelayan tradisional yang sudah turun-temurun, yakni hak eksploitasi sumberdaya di wilayah laut tertentu terbatas hanya untuk orang-orang dalam kelompok sosial wilayah tersebut. Namun dengan perkembangan zaman sebagian lagi dari nelayan menganut paham open access.

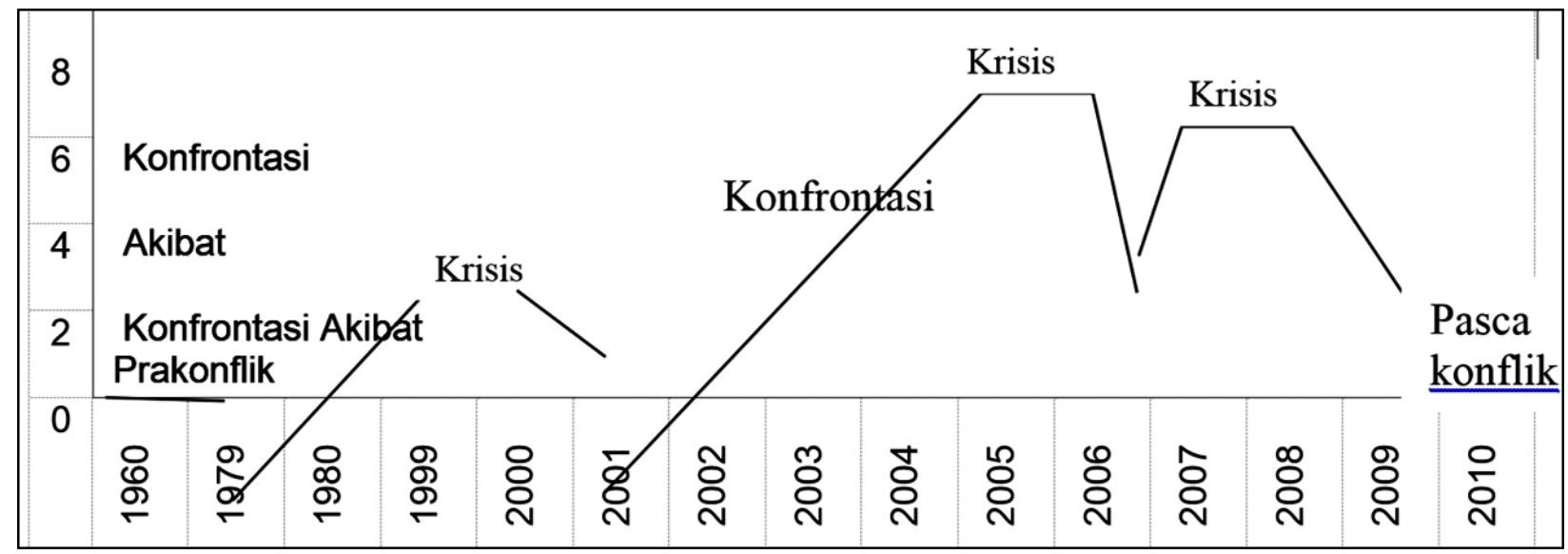

Keterangan:

Sumbu $\mathrm{x}=$ Tahun / Year

Sumbu y = Penahapan konflik / Conflict escalation

Krisis = tindakan anarkis (>2) kekerasan fisik (>4) penyanderaan kapal dan (>6) pembakaran kapal

Gambar 1. Grafik penahapan konflik Nelayan di Kabupaten Kotabaru Kalimantan Selatan.

Figure 1. Graph of fishermen conflict phase in Kotabaru district, South Kalimantan.

Pada periode ini mulai terdapat teknologi baru atau melakukan modifikasi terhadap alat tangkap, kualitas dan kapasitas yang berbeda pada fishing ground yang sama. Hal ini membuat kenyamanan nelayan merasa terganggu. Di perairan Kotabaru pada periode ini pula mulai terjadi teguran-teguran bahkan terjadi pertikaianpertikaian di laut dalam bentuk penolakan terhadap penggunaan alat tangkap yang berbeda. Nelayan setempat memberikan peringatan-peringatan baik lisan maupun tertulis dan membuat perjanjianperjanjian, walaupun pada akhirnya banyak yang melangar kesepakatan yang dibuat. Beberapa langkah pengamanan telah dibuat seperti mengadakan perpolisian masyarakat oleh pihak kepolisian, pembinaan dan sosialisasi oleh Dinas Perikanan dan Kelautan.

Kasus konflik daerah tangkap belum berakhir; pada tahun 2000-2005 terjadi lagi konfrontasi. Protes terhadap adanya pengkavlingan daerah penangkapan, dianggap menimbulkan ketidakadilan terutama oleh pengguna lampara dasar modifikasi. Menentukan tapal batas dengan cara membuat patok batas wilayah perairan tempat operasional nelayan tradisional, menetapkan wilayah-wilayah tertentu yang dilarang beroperasinya nelayan pengguna alat tangkap lampara dasar mini atau lainnya dan melakukan razia justru menimbulkan konflik yang lebih luas.
Pada tahun 2004 untuk menertibkan konflik daerah penangkapan yang diperebutkan oleh nelayan di Kotabaru, maka dilakukan pertemuan antar nelayan. Diskusi dihadiri oleh Bupati Kotabaru, Kapolres, nelayan Kecamatan Kelumpang Selatan, Kecamatan Kelumpang Tengah, Kecamatan Pulau Sebuku, Kecamatan Pulau Laut Utara dan Dinas Kelautan dan Perikanan Kotabaru. Kapolres menyarankan untuk menciptakan areal tangkapan baru, kemudian Dinas Kelautan dan Perikanan Kotabaru menyetujui pembagian wilayah penangkapan ditertibkan kembali.

Periode tahun 2000, 2005-2006 dan 2007-2008 (krisis). Pada waktu itu telah terjadi pengkavlingan wilayah penangkapan ikan. Kemudian apabila ada orang luar yang masuk ke wilayah yang terlarang bagi alat tangkap tertentu maka terjadi pengusiran, kekerasan fisik dan perusakan alat tangkap, penyitaan dan bahkan penenggelaman kapal. Aksi ini dilakukan karena nelayan dianggap melakukan pelanggaranpelanggaran atas kesepakatan yang telah dibuat. Sebelumnya sudah pernah disepakati masalah jalur penangkapan dengan memberikan patok dari halayung (tiang bakang) namun karena hanya bisa bertahan setahun, batas tersebut hancur diterpa ombak. Selain itu pada periode ini konflik menjadi terbuka, saling tuduh bahwa jalur penangkapan yang disepakati telah digeser secara illegal. 
Organisasi INSAN (Ikatan Nelayan Saijaan) melakukan negosiasi untuk diselesaikan secara kekeluargaan dan mengharapkan tidak melakukan pengkavlingan laut dan berjanji bahwa nelayan pengguna alat tangkap lampara dasar atau yang memiliki teknologi lebih tinggi tidak akan memasuki wilayah selat Laut dan selat Sebuku yang diperuntukkan oleh nelayan tradisonal. Namun karena kasus tersebut sudah berdampak pada kekerasan fisik penyelesaian konflik dibantu oleh pihak kepolisian. Organisasi INSAN mendesak Dinas Kelautan dan Perikanan dan aparat yang berwenang untuk melakukan tindakan hukum kepada pelaku. DKP Kotabaru berjanji untuk membantu pembebasan perahu nelayan yang ditahan oleh nelayan dan membantu proses pengantian kerusakan atau dampak yang ditimbulkan oleh konflik tersebut.

Tahun 2001, 2006-2007 dan 2009 (akibat). Walaupun konflik berakhir sejalan dengan berakhirnya musim utara (Januari-April) maka untuk sementara kehidupan nelayan tampak harmonis dan konflik berakhir dengan sendirinya, namun pengkavlingan laut dengan patok tiang bakang masih dilakukan.

Periode 2010-sekarang (pascakonflik). Pada periode ini walaupun tidak terdapat konflik, nelayan tetap memperjuangkan hak mereka untuk dapat melakukan aktivitas berusaha dalam kondisi yang aman. Nelayan meminta dukungan dari semua pihak yang dianggap dapat menyelesaikan permasalahan mereka. Pokmaswas yang terbentuk semakin aktif dalam melakukan pengawasan dan menghimpun segala permasalahan nelayan.

\section{Pemetaan Permasalahan Konflik}

Beberapa nelayan di Kotabaru masih menerapkan adanya pola penguasaan dan kepemilikan wilayah laut oleh kelompok masyarakat. Pola tersebut terbagi berdasarkan zona daerah tangkap nelayan tradisional yang sudah turun-temurun, yakni hak eksploitasi sumberdaya di wilayah laut tertentu terbatas hanya untuk orang-orang dalam kelompok sosial wilayah tersebut. Pembagian wilayahnya masing-masing yang terbagi dalam 6 daerah penangkapan (Gambar 2).

Berdasarkan peta batimetri, perairan di Selat Makasar sekitar perairan Kalimantan Selatan mempunyai kedalaman bervariasi yaitu: sebelah barat merupakan perairan dangkal $(<50 \mathrm{~m})$ dan akan semakin dalam di bagian timurnya hingga kedalaman $(>100 \mathrm{~m})$. Kedalaman di sekitar pulau Sebuku mempunyai kedalaman bervariasi, yaitu dengan kisaran kedalaman (20-700m).

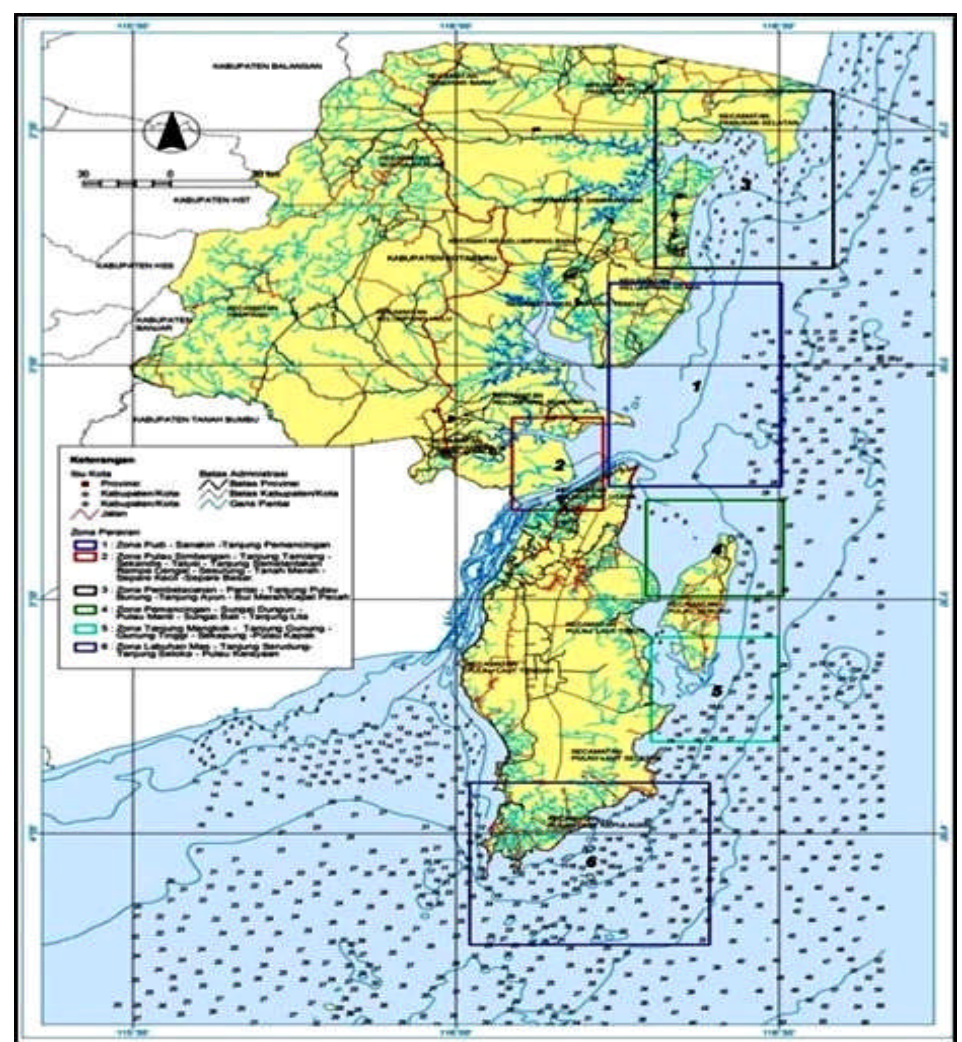

Gambar 2. Pembagian Daerah penangkapan ikan di Kabupaten Kotabaru.

Figure 2. Division of Fishing Ground in Kotabaru Regency. 
Tabel 1. Pola musim udang di Kabupaten Kotabaru

Table 1. The pattern of shrimp season in Kotabaru regency

\begin{tabular}{|c|c|c|c|c|}
\hline No & Musim & Bulan & Potensi Udang & Perairan \\
\hline 1 & Musim Utara & Januari-April & maksimum & $\begin{array}{l}\text { Selat laut: Senakin, Tg Gunung, Karang } \\
\text { Piring, Tg Pemancingan, Pulau Manti, Sei } \\
\text { Dungun, Tg Lita, Pulau Kapak. }\end{array}$ \\
\hline 2 & $\begin{array}{l}\text { Musim Barat } \\
\text { Pancaroba }\end{array}$ & Mei & Minimum & Selat laut \\
\hline 3 & $\begin{array}{l}\text { Tenggara } \\
\text { (angin } \\
\text { Selatan) }\end{array}$ & Juni-Sept & Maksimum & $\begin{array}{l}\text { Senakin,Tg Dewa, Tg Gunung, Tg Ayun, } \\
\text { Karang piring, Sebuli, Senakin, } \\
\text { Pembelacangan, Pulau Kapak }\end{array}$ \\
\hline 4 & Musim Barat & Oktober-Des & Minimum & Selat Laut, Pulau Sebuku \\
\hline
\end{tabular}

Sumber: Data primer diolah

Konflik perebutan daerah penangkapan berkaitan dengan musim udang, antara lain udang windu (Penaeus monodon), udang putih (Penaeus indicus), udang jerbung (Penaeus merguensis), udang cat (Parapenaeopsis sculiptilis) dan udang lurik (Metapenaeus canaliculatus). Dalam satu tahun terdapat 3 (tiga) musim yaitu: (1) musim Utara (2)

musim Barat/pancaroba dan (3) musim Tenggara (Tabel 1).

\section{Identifikasi Tipologi konflik}

Tipologi konflik perikanan tangkap yang terjadi di perairan Kotabaru seperti yang disajikan pada Tabel 2.

Tabel2. Tipologi konflik nelayan di Kotabaru Kalimnatan Selatan

Table 2. Typology of fishing conflict in Kotabaru, South Kalimantan

\begin{tabular}{|c|c|c|c|}
\hline Penyebab utama & Ekses & $\begin{array}{l}\text { Tipologi } \\
\text { konflik }\end{array}$ & Pihak yang terlibat \\
\hline $\begin{array}{l}\text { 1. Perebutan daerah } \\
\text { penangkapan seirama dengan } \\
\text { perputaran potensi } \\
\text { sumberdaya udang yang } \\
\text { tersebar di beberapa wilayah } \\
\text { Kotabaru } \\
\text { 2. Pengkavlingan laut menjadi } \\
\text { hak property }\end{array}$ & $\begin{array}{l}\text { Bentrokan fisik, } \\
\text { penganiayaan } \\
\text { perusakan, } \\
\text { penyitaan dan } \\
\text { penenggelaman } \\
\text { kapal, }\end{array}$ & $\begin{array}{l}\text { Yurisdiksi } \\
\text { Perikanan }\end{array}$ & $\begin{array}{l}\text { Nelayan Kec. Pulau laut } \\
\text { Utara vs Kec. Pulau } \\
\text { Sebuku Kotabaru, Walhi, } \\
\text { INSAN, DKP Daerah, } \\
\text { Kepolisian }\end{array}$ \\
\hline $\begin{array}{l}\text { 1. Modifikasi lampara dasar, } \\
\text { penambahan danleno diisi } \\
\text { dengan semen agar dapat } \\
\text { mengeruk dasar perairan dan } \\
\text { membuka mulut jaring } \\
\text { kemudian nelayan mengganti } \\
\text { danleno tersebut dengan papan }\end{array}$ & \multirow[t]{2}{*}{ Perkelahian } & $\begin{array}{l}\text { Alokasi } \\
\text { internal, }\end{array}$ & \multirow[t]{2}{*}{$\begin{array}{l}\text { Nelayan lampara dasar vs } \\
\text { nelayan trammel net, DKP } \\
\text { Daerah, Pokmaswas }\end{array}$} \\
\hline $\begin{array}{l}\text { layang (otter board). } \\
\text { 2. Pelanggaran jalur-jalur } \\
\text { penangkapan, } \\
\text { mengoperasikaanya di wilayah } \\
\text { perikanan tradisional }\end{array}$ & & \multirow[t]{2}{*}{$\begin{array}{l}\text { Mekanisme } \\
\text { pengelolaan }\end{array}$} & \\
\hline Sumber : Data Primer diolah & & & \\
\hline \multicolumn{2}{|c|}{$\begin{array}{l}\text { Lemahnya mekanisme pengelolaan terjadi pada } \\
\text { kasus daerah penangkapan karena pemerintah yang } \\
\text { telah memberi persetujuan terhadap pembagian } \\
\text { daerah penangkapan di perairan Kotabaru. Hal ini } \\
\text { menumbuhkan adanya pihak yang bertolak belakang } \\
\text { dan dipersepsikan ketidakadilan pemerintah karena } \\
\text { kemungkinan terjadi pengkavlingan laut pada fishing } \\
\text { ground yang memiliki potensi sumberdaya yang tinggi } \\
\text { dan ada yang memiliki potensi rendah. Dengan }\end{array}$} & \multicolumn{2}{|c|}{$\begin{array}{l}\text { demikian terjadi tumpang tindih pemberlakuan otonomi } \\
\text { daerah dan ikut campurnya pemerintah pusat } \\
\text { terhadap kebijakan pemerintah daerah. } \\
\text { Konsepsi eksploitasi sumberdaya perikanan yang } \\
\text { dianut oleh nelayan Kecamatan Pulau Sebuku } \\
\text { menganut eksploitasi perikanan dengan alat tangkap } \\
\text { tradisional yang telah turun temurun, telah dianggap } \\
\text { sebagai hak property bagi mereka, sehingga apabila }\end{array}$} \\
\hline
\end{tabular}


nelayan luar masuk ke wilayah tersebut apalagi memiliki alat tangkap yang tidak sama telah dianggap melanggar norma dan tidak menjaga kelestarian sumberdaya perikanan.
Konflik alokasi internal terjadi karena adanya kecemburuan sosial terhadap nelayan yang memiliki teknologi yang lebih tinggi dari nelayan lain dalam menangkap jenis ikan yang sama.

\section{Identifikasi sikap, perilaku dan konteks sebagai faktor yang mempengaruhi konflik}

\begin{tabular}{|c|c|}
\hline $\begin{array}{l}\text { Pandangan nelayan } \\
\text { terhadap nelayan } \\
\text { lampara dasar } \\
\text { modifikasi, namun } \\
\text { penggunaannya } \\
\text { dapat } \\
\text { mengakibatkan over } \\
\text { fishing }\end{array}$ & $\begin{array}{l}\text { Perilaku yang terjadi yaitu } \\
\text { menegur dan mengusir nelayan } \\
\text { yang menggunakan lampara dasar } \\
\text { modifikasi (mini trawl). } \\
\text { C Konteks } \\
\text { Sumberdaya ikan merupakan potensi } \\
\text { yang dapat habis dan kepastian } \\
\text { hukum tentang penggunaan lampara } \\
\text { dasar modifikasi }\end{array}$ \\
\hline
\end{tabular}

Gambar 3. Prinsip "Sikap-Perilaku-Konteks" Konflik Nelyan.

Figure 3. The "Context-Behavior" Principles of Fisherman Conflict.

\section{Resolusi Konflik}

Upaya yang telah dilakukan untuk menyelesaikan konflik yang terangkum dalam status penyelesaian konflik daerah penangkapan dan penggunaan alat tangkap lampara dasar modifikasi (mini trawl) disajikan pada Tabel 3.

Tabel 3. Status penyelesaian konflik pada kasus daerah penangkapan dan penggunaan mini trawl Table 3. Status of conflict resolution in the case of fishing ground and the use of mini trawl

\begin{tabular}{llc}
\hline No & \multicolumn{1}{c}{ Status penyelesaian konflik } & $\begin{array}{c}\text { Teknik resolusi } \\
\text { konflik }\end{array}$ \\
\hline Kasus Daerah Penangkapan & \\
\hline 1 & $\begin{array}{l}\text { Nelayan Sungai Dungun melakukan penangkapan ikan di wilayah nelayan } \\
\text { Dirgahayu. }\end{array}$ & Negosiasi \\
2 & $\begin{array}{l}\text { Nelayan Dirgahayu melakukan penangkapan ikan di wilayah Sungai } \\
\text { Dungun. Diselesaikan dengan cara penyitaan alat tangkap dan perahu }\end{array}$ & Negosiasi \\
3 & $\begin{array}{l}\text { Dilakukan pembatasan jalur penangkapan memberikan patok dari halayung } \\
\text { (tiang bakang) sebagai batas zone pengangkapan ikan, yang difasilitasi oleh }\end{array}$ & Negosiasi \\
& $\begin{array}{l}\text { DKP Kotabaru. Namun karena hanya bisa bertahan setahun, batas tersebut } \\
\text { hancur diterpa ombak. }\end{array}$ & \\
4 & $\begin{array}{l}\text { Pengurus INSAN (Ikatan Nelayan Saijaan) mengadukan ke DPRD Kotabaru } \\
\text { dengan mengajukan masalah (i) pembagian wilayan tangkap (ii) larangan } \\
\text { melaut di pulau kapak }\end{array}$ & Avoidance \\
\hline
\end{tabular}
Sumber : Data Primer diolah

\section{Kelembagaan Penyelesaian Konflik}

Hubungan keterlibatan antara masing-masing pihak dalam penyelesaian konflik divisualisaikan kedalam peta konflik (Gambar 4). Pihak yang berkonflik antara A dan B, secara tidak langsung melibatkan lembaga-lembaga pemerintah dan non pemerintah dalam penyelesaiannya. Situasi Harmonis dan tidak harmonispun dapat terjadi antara beberapa lembaga tersebut. Nilai (+) melambangkan kesaaman persepsi dan saling mendukung antar lembaga sedangkan nlai (-) melambangkan adaya perbedaan persepsi dan menyeabkan kurang harmonisnya antar lembaga. 
Pengembangan kelembagaan dilakukan dengan menciptakan jejaring komunikasi dan interaksi antar kelompok masyarakat dan terorganisir dalam bentuk Sistem pengawasan Sumberdaya Kelautan dan Perikanan Berbasis masyarakat dengan menerapkan Alternative Dispute Resolution (ADR). Upaya penyelesaian konflik tersebut sangat membutuhkan perhatian dari pemerintah terutama polsek/polres, kemudian dilakukan pengarahan oleh Kapolres agar masyarakat nelayan dapat melaut dengan aman, nyaman, dan hasil memadai. Nelayan tradisional dalam upaya memperjuangkan hak mereka memilih melakukan aliansi dengan pihak luar, dalam hal ini lembaga non pemerintah seperti WALHI (Wahana Lingkungan Hidup).

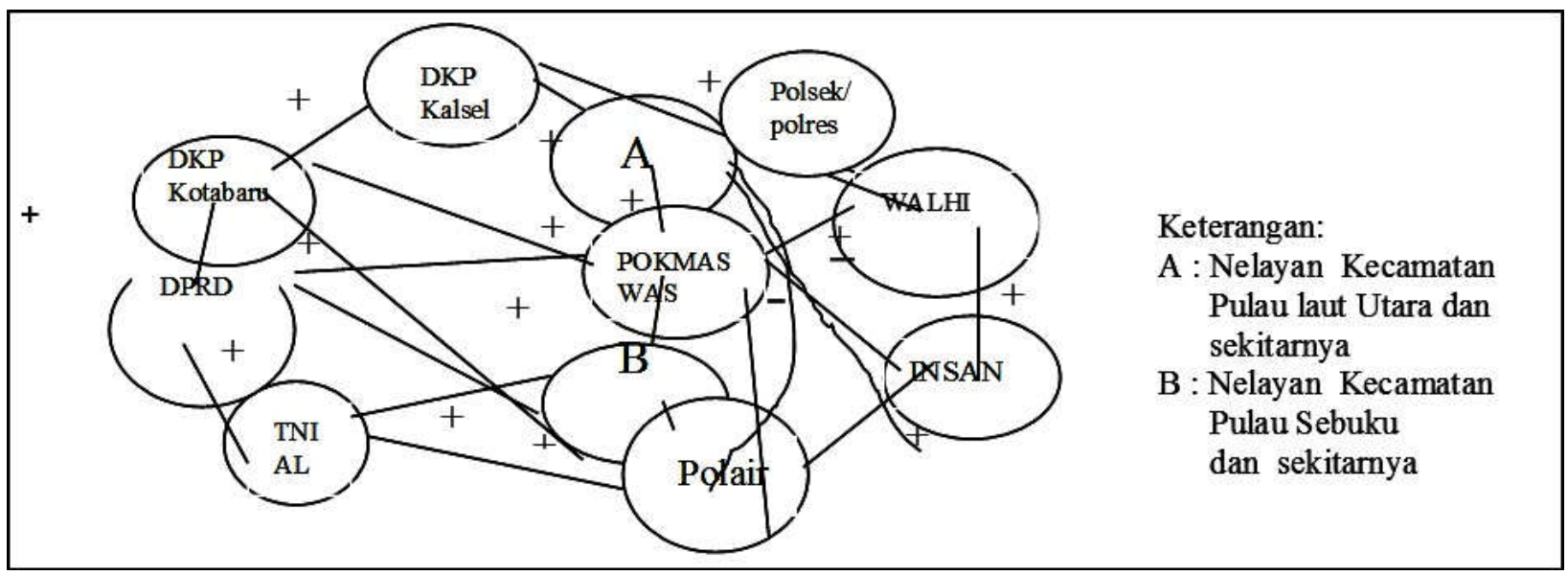

Gambar 4 Peta institusi dalam penyelesaian kasus konflik daerah penangkapan.

Figure 4. Map of the institution in the settlement of cases of conflicts of fishing ground.

Dengan kekuatan moral dan sebagai pemerhati lingkungan hidup WALHI sebagai pendamping turut berpartisipasi. Pokmaswas merupakan pelaksana pengawasan di tingkat lapangan yang terdiri dari tokoh masyarakat, tokoh agama, tokoh adat, LSM, nelayan, petani ikan serta mayarakat maritim lainnya. Pokmaswas dibentuk atas inisiatif masyarakat yang difasilitasi oleh unsur seorang anggota masyarakat.

\section{PEMBAHASAN}

\section{Permasalahan Konflik Nelayan}

Pengenalan tipologi konflik merupakan hal penting untuk menjelaskan penyebab terjadinya konflik. Yulikasari et al. (2010) menyatakan faktor mendasar pendorong terjadinya konflik belum banyak mendapat perhatian dan dijadikan dasar dalam penyelesaiannya. Salah satu faktor peyebab konflik adalah faktor yuridis yaitu keberadaan peraturan dan perundangan yang mengatur pemanfaatan sumberdaya perikanan yang tidak sesuai dengan karakteristik daerah dan sistem nilai yang berlaku di masyarakat.

Konflik yuridiksi merupakan perwujudan konsep kepemilikan (property right). Persepsi nelayan Selat Laut, sebagai orang lokal mempunyai hak prioritas untuk mengeksploitasi sumberdaya yang berada di sekitar tempat mereka dan tidak berkenan atas kehadiran nelayan luar, maka terpicu konflik yang bernuansa kekerasan. Anggapan masyarakat terhadap kepemilikannya terhadap laut tersebut sejalan dengan anggapan Adhuri (2005) yang menjelaskan bahwa ada keterkaitan antara identitas sebuah kelompok sosial dengan tempat dimana mereka hidup.

Berdasarkan eskalasi konflik terlihat bahwa perkembangan konflik mulai dari konfrontasi hingga kritis sering terjadi pada era otonomi, sehingga sering digeneralisasi dengan konflik identitas. Meski demikian menurut Satria (2002) bahwa upaya generalisasi konflik-konflik nelayan sebagai konflik identitas akibat diterapkannya otonomi daerah adalah kurang tepat. Undang-Undang No. 23 tahun 2014 tentang otonomi daerah, dimana pemerintah provinsi mempunyai kewenangan untuk pengelolaan wilayah laut dan sumberdaya di dalamnya hanya 8 mil ke arah laut lepas, sehingga memberi peluang yang besar untuk nelayan andon dari luar daerah bebas melakukan penangkapan pada jalur $>8$ mil.

Berkaitan dengan akar permasalahan konflik, jika dicermati berdasarkan kategori sumber konflik Gorre (1999), konflik yang bersumber pada masalah hubungan yaitu perbedaan persepsi karena faktor emosional yang kuat, asumsi terhadap perilaku pihak lain, kurang atau tidak ada komunikasi, ataupun adanya perilaku negatif yang berulang. Kegiatan pemanfaatan sumberdaya perikanan yang dianggap dapat merusak dan berpotensi mengancam 
kelestarian sumberdaya perikanan. Masalah hubungan terjadi pada kasus lampara dasar, yaitu adanya persepsi yang negatif dan kurangnya komunikasi antara nelayan.

Konflik yang bersumber pada masalah struktural yang ditunjukkan oleh adanya ketidakjelasan kebijakan yang dibuat oleh Dinas Perikanan Kabupaten Kotabaru yang menyetujui adanya pembagian daerah penangkapan. Ketidakadilan yang dimaksud sehubungan dengan timpangnya perlakuan yang diberikan dalam mengakses sumberdaya seperti pemberian izin kepada pihak yang memiliki teknologi yang lebih tinggi. Hal tersebut sejalan dengan Pollnac (1984) yang diacu dalam Wahyono et al. (2000) menyatakan suatu sumber konflik yang utama adalah peningkatan intensitas eksploitasi. Hal ini berhubungan dengan pertambahan unit eksploitasi dan perubahan teknologi. Berdasarkan beberapa penelitian, konflik bisa terwujud oleh perbedaan nilai seperti pada penelitian Hasan (1974) bahwa wujud konflik antar nelayan juga ditimbulkan oleh adanya perbedaan nilai. Hal ini sejalan dengan penelitian Yulikasari et al. (2010) menyatakan wujud konflik antar nelayan juga ditimbulkan oleh adanya perbedaan nilai, kepentingan dan konflik diantara mereka yang berada dalam posisinya sama. Modernisasi pada sektor perikanan tangkap telah terbukti memperbesar arus eksploitasi yang berujung pada kerusakan ekosistem laut dan over fishing serta kerawanan sosial antar nelayan akibat persaingan dalam pemanfaatan sumberdaya perikanan.

\section{Resolusi Konflik}

Resolusi konflik dengan teknik litigasi dilakukan pada kasus daerah penangkapan disebabkan oleh adanya bentrokan atau kekerasan fisik dan penenggelaman kapal, namun dalam kenyataannya teknik litigasi yang digunakan ternyata justru memicu munculnya konflik ikutan dan mendorong timbulnya kemarahan antar kelompok. Hal tersebut sejalan dengan apa yang tertuang dalam KKP (2002) bahwa resolusi konflik dengan teknik litigasi disamping mempunyai keuntungan karena dijalankan oleh para profesional namun juga memiliki kelemahan karena menghasilkan pihak yang menang, pihak yang kalah dan perpecahan dalam masyarakat. Begitupula dengan pendapat Bennet and Nelland (2000) bahwa proses konflik yang menggunakan hukum formal (litigasi) akan menghasilkan suasana yang terisolasi karena ada pihak yang dimenangkan dan dikalahkan.

Negosiasi yang dilakukan pada pada resolusi konflik nelayan di Kobaru memiliki kelemahan, semestinya bisa dilakukan dengan melewati beberapa tahap. Sebagaimana yang telah dikemukakan oleh Morris (2002) yaitu: tahap pertama menunjuk kepada kondisi yang harus ada untuk semua pihak untuk masuk kepada ruang negosiasi tanpa kekerasan. Kondisi yang mendahului negosiasi mengidentifikasi bahwa: semua pihak yang terlibat konflik harus memahami bahwa di antara mereka terdapat perbedaan pandangan dan atau kepentingan, mereka harus memiliki kemauan untuk menyelesaikan konflik dengan opsi anti kekerasan, mereka harus punya kepentingan bersama (common interests) dalam kesepakatan dan memperoleh keuntungan bersama melalui saling memahami yang dituangkan dalam kesepakatan bersama itu. Jika satu sisi dapat menjatuhkan keputusan, sisi yang lain sebaiknya mengambil sikap agar isu itu tidak dimasukkan ke dalam suatu negosiasi. Kemudian pada tahap kedua, ketika suatu keputusan untuk negosiasi dilakukan, langkah selanjutnya adalah melakukan komunikasi berulang-ulang tentang bentuk inti dari negosiasi. Banyak faktor penentu dalam proses ini. Faktor-faktor tersebut termasuk beberapa pokok yaitu: komposisi tim negosiasi, persepsi pihak lawan berkaitan dengan pihak lainnya, sifat dasar dan saluran-saluran komunikasi, kepentingan relatif manusia versus isu, struktur negosiasi, gaya penawaran dan manfaat pihak ketiga.

Sebagaimana yang dinyatakan Morris (2002), terdapat dua faktor yang menentukan mutu hasil negosiasi adalah (1) masukan menuju pengambilan keputusan (decision making) oleh kedua belah pihak; dan (2) format yang digunakan untuk membuat persetujuan (form of agreement). Pada faktor pertama, proses pengambilan keputusan adalah ciri dasar dari kegiatan negosiasi; proses ini haruslah dikelola secara hati-hati dan sensible dalam perjalanan negosiasi. Hal yang sering terjadi dalam pengambilan keputusan adalah bagaimana keputusan itu seharusnya dibuat daripada bagaimana keputusan itu dibuat. Sedangkan pada faktor kedua, ketika sebuah kesepakatan dihasilkan, satu pertanyaan penting adalah apakah kesepakatan tersebut berbentuk formal atau informal, karena kebanyakan kesepakatan dibuat secara formal dan tertulis. Dalam situasi tertentu, suatu kesepakatan tertulis mungkin ditambahkan melalui suatu kesepahaman informal. Dalam beberapa budaya, mekanisme pelaksanaan kesepakatan itu bersifat personal. Orang meletakkan komitmennya kepada manusia, bukan pada kontrak. Mereka memberi tekanan kepada hubungan antar manusia dan bukan pada kesepakatan-kesepakatan tertulis.

Resolusi konflik daerah tangkap yang telah dilakukan dengan teknik fasilitasi, belum dapat menyelesaikan masalah, disebabkan prekondisi yang 
kurang mendukung adanya pengkavlingan laut. Adanya hukum dan peraturan lain mengenai otonomi daerah tentang pembagian wilayah laut kabupaten, anggapan open acces dan perbedaan kondisi geografis sementara kenyataan bahwa sumberdaya yang dimiliki sudah sangat menurun atau telah terjadi degradasi. Hal ini sangat sulit untuk diterapkannya suatu aturan. Dalam hal ini salah satu cara efektif adalah pengorganisasian. Malik et al. (2003) menyatakan bahwa dengan mengorganisir, para pihak yang terlibat di dalamnya dapat saling belajar satu sama lain. Pada satu sisi, para outsiders dapat belajar dari berbagai pengalaman tentang masalah komunitas setempat maupun masalah komunitas-komunitas lain. Para outsiders dapat mentranspormasikan pengalaman, ilmu maupun dana untuk mendukung penguatan komunitas setempat.

\section{Kelembagaan Pengelolaan Konflik}

Kelembagaan yang berperan dalam resolusi konflik yaitu DKP saling tidak mendukung (antagonis), disatu sisi DKP menyetujui adanya pembagian daerah penangkapan, disisi lain INSAN (Ikatan Nelayan Saijaan) tidak menyetujui resolusi tersebut. Memperhatikan hal tersebut yaitu berlakunya otonomi daerah dan tumpang tindihnya kebijakan seringkali memunculkan suatu interaksi antagonis antara lembaga-lembaga tersebut. Untuk menghasilkan sinergitas kinerja dari lembaga yang mengelola konflik di perairan Kalimantan Selatan, diperlukan kelembagaan yang dapat mengatur keterpaduan semua lembaga pengelolaan konflik dalam pengembangan usaha perikanan tangkap. Hal ini sejalan dengan apa yang dikemukakan oleh Purwaka (2003) yang menyatakan bahwa sinergitas dalam berinterakasi dari lembaga-lembaga tertentu merupakan hal ideal yang diharapkan oleh semua pihak.

Komponen kelembagaan memegang peranan penting dalam pengembangan perikanan tangkap, karena kemajuan teknologi alat penangkapan ikan yang terjadi justru menimbulkan konflik dalam pemanfaatan sumberdaya ikan. Salah satu langkah strategis yang dapat dilakukan dalam pengembangan usaha perikanan tangkap di perairan Kalimantan selatan yaitu: (1) pengembangan kapasitas peran kelembagaan pengelola dan (2) sumberdaya manusia yang dapat mendukung upaya pengembangan tersebut. Pada upaya pengembangan kapasitas peran kelembagaan terutama kelembagaan non pemerintah sebagai inisiator untuk dapat mengakomodasi kebijakan sesuai dengan kondisi wilayah dan isu lokal yang dapat mempengaruhi peran kelembagaan pemerintah sebagai regulator. Pemahaman terhadap berbagai kewenangan sektoral yang diberikan oleh peraturan perundang-undangan dari masing-masing sektor yang bersangkautan.

Budaya sebagai pedoman hidup masyarakat terdiri atas nilai-nilai dan norma-norma yang tertib meliputi norma kesopanan dan norma hukum. Budaya tidak dapat dilepaskan dari masyarakat karena antara keduanya erat hubungannya. Budaya tidak akan lahir tanpa adanya masyarakat, demikian pula sebaliknya. Sejalan dengan pendapat Michael (2002) menyebutkan bahwa dalam kehidupan masyarakat manusia memerlukan pedoman, yaitu budaya sebagai alat perangkat kebutuhan integratif. Begitupula yang dinyatakan oleh Ostrom (1993) bahwa tanpa adanya norma tersebut niscaya kehidupan akan penuh kekacauan, manusia akan kehilangan arah dan pedoman hidup, akibatnya manusia menjadi liar dan hidup seperti hewan.

\section{KESIMPULAN DAN SARAN Kesimpulan}

1. Konflik nelayan pada kasus pembagian daerah penangkapan ikan merupakan tipologi yuridiksi perikanan, nelayan masih menganut pola pembagian zona daerah penangkapan tradisional. Konflik nelayan pada kasus perbedaan alat tangkap tradisional dan modifikasi termasuk tipologi alokasi internal dan mekanisme pengelolaan. Permasalan lainnya lainnya yang memicu konflik adalah adanya perbedaan posisi, kebutuhan, kepentingan, pandangan dan konteks dikalangan nelayan.

2. Resolusi konflik lampara dasar modifikasi diselesaikan dengan cara negosiasi secara kekeluargaan, tidak ada kesepakatan tertulis. Wakil dari kelompok nelayan selalu berinisiatif untuk menemui wakil dari pihak lawan untuk melakukan negosiasi terhadap permasalahan yang dihadapi. Jika mengalami kegagalan, mereka akan menghubungi pihak ketiga (misalnya dari unsur musyawarah pimpinan kecamatan/Muspika) untuk melakukan intervensi. Resolusi konflik dapat juga terjadi seara avoidance yang mana berhenti dengan sendirinya berdasarkan kesadaran masingmasing. Pada kasus daerah penangkapan resolusi dilakukan dengan melakukan negosiasi untuk diselesaikan secara kekeluargaan dengan perjanjian tidak memasuki wilayah selat laut dan selat sebuku yang diperuntukkan oleh nelayan tradisonal.

3. Lembaga yang terlibat dalam penyelesaian konflik yaitu DKP Kalsel, DKP Kotabaru, INSAN, TNI AL,Polair, Polres/Polsek, WALHI, DPRD, POKMASWAS. Untuk mengatasi terjadinya 
konflik sekunder antara lembaga-lembaga tersebut, maka POKMASWAS dapat dikembangkan sebagai lembaga pengelolaan konflik yang fleksibel dalam mengikuti adanya eskalasi konflik atau dengan membentuk komite penasihat yang dapat memfasilitasi, menampung dan memberikan pertimbangan-pertimbangan yang dapat memfasilitasi resolusi konflik dengan konsep Alternative Dispute Resolution (ADR)

\section{Rekomendasi}

Penyelesaian hendaknya dilakukan secara kooperatif dengan mengedepankan output yang lebih dapat diterima oleh semua pihak yang berkonflik dan hasilnya lebih berorientasi jangka panjang

Diperlukan upaya untuk membuat legitimasi terhadap kelembagaan masyarakat seperti Pokmaswas sebagai kelembagaan yang tidak bersifat ad Hoc, menerapkan Alternative Dispute Resolution (ADR) yaitu pengambilan keputusan yang didasarkan pada keahlian atau pengetahuan yang dapat dikompromikan

Perlu adanya peraturan daerah untuk mengatur dan menata pengelolaan sumberdaya perikanan dengan memasukkan nilai-nilai yang berkembang di masyarakat. Disamping itu, Jaringan kelembagaan yang sudah terbentuk perlu di tingkatkan dengan memiliki teknologi komunikasi yang tinggi, agar komunikasi dapat berjalan lancar dan informasi dapat diterima dengan cepat sehingga pengelolaan konflik dapat berjalan lancar.

\section{Persantunan}

Ucapan terimakasih disampaikan kepada semua lembaga yang berperan dalam penyelesaian Konflik Nelayan antara lain: DKP, WALHI, TNI AL, POKMASWAS dan Nelayan Kotabaru sebagai informan dari penelitian ini serta Dekan FPK Unlam Banjarbaru yang telah memberikan izin dan dukungan dalam penyelesaian penelitian ini.

\section{DAFTAR PUSTAKA}

Adhuri, D.S. Ed. (2005). Fishing in, Fishing out: Memahami Konflik Kenelayanan di Kalimantan Timur dan Nusa Tenggara Timur (p. 122). PMBLIPI. Jakarta.

Bennett, E., \& Neiland, A. (2000). Review of study approach to conflicts (p. 122). Centre For the Economics and Management Of Aquatic Recources (CEMARE).
Gorre, I.R.L. (1999). The basics of appropriate dispute resolution: A Must Read for Coastal Managers. Journal of Tropical Coasts, 6, 3-7.

Hasan, S.Z.S. (1974). A Situational Analysis of Conflict in A Fishing Fillage. Journal of Science. 5, 43544.

KKP. Kementrian Kelautan dan Perikanan. (2002). Penyusunan Pedoman Pengelolaan Sengketa Pengelolaan Sumberdaya Kelautan dan Perikanan (SDKP) di luar Peradilan melalui mekanisme Alternative Dispute Resolution (ADR). Proyek Pengembangan Kelembagaan Pengelolaan Laut. Jakarta.

Malik, I., Fauzi, N., Wijardjo, B., \& Royo, A.G. (2003). Menyeimbangkan kekuatan pilihan strategi penyelesaian konflik atas sumberdaya alam (Ed. Pellokila YK, Prasetyohadi, Trisasongko D). Gram Pruit DG, Rubin JZ. 1986. Sosial Conflict; Escalation, Stalemate and Settlement. Random House. New York.

Morris, D. (2002). Communities, building, authority, responsibility and capacity in the case against the global economy and for a turn toward the local. Editor (Ed.), Jerry Mander and Edward Goldsmith. Tibbra Club Books

Michael, F. (2002). Local communities as learning organization: The Case of The Village of Toro, Sentral Sulawesi. Indonesia.

Ostrom, E. (1993). The sustainable economict. Journal of Science, 56, 14-17.

Pollnac RB. (1984). Investigating Territorial Use Rights Among Fishermen. J Senri Ethnological Studies. 17, 285-300.

Priscoli, J.D. (2002). Participation, consensus building and conflict management training course (p. 179). UNESCO - IHP.

Purwaka. (2003). Bunga rampai analisis pengembangan kapasitas kelembagaan kelautan dan perikanan (p. 37). Fakultas Perikanan dan IImu Kelautan. Program Pascasarjana. Tidak diterbitkan.

Rusmilyansari. (2012). Root problem and conflict resolutian of fisheries in sea waters of South Kalimantan. Journal of Coastal Development: 15 , 243-251

Rusmilyansari, Rosadi, E., \& Apriansyah. (2013). 
Tipologi konflik sumberdaya perairan di perairan Kalimantan Selatan. Buletin PSP. 21, 247-354.

Satria A. (2004). Konflik nelayan dan otonomi Daerah. Konferensi Nasional IV Pengelolaan Sumberdaya perairan Umum, Pesisir, Pulau-pulau Kecil dan Laut Indonesia. Balikpapan 14-17 Desember. Kalimantan Timur.

Wahyono A. (2000). Hak ulayat laut di kawasan Timur Indonesia (p. 60). Yogyakarta. Media Pressindo. hal.
Yulikasari, T.E., Wisudo, S.H., Monintja, D.R., \& Purwaka, T. (2010). Konflik perikanan tangkap di perairan Kabupaten Bengkalis Provinsi Riau. Marine Fisheries Journal Teknologi dan Manajemen Perikanan Laut, 1, 113-210. https://doi.org/ 10.29244/jmf.1.2.11-20. 